\title{
Cooperative-waqf model: a proposal to develop idle $w a q f$ lands in Malaysia
}

\author{
Anwar Allah Pitchay \\ School of Management, Universiti Sains Malaysia, Penang, Malaysia \\ Mohamed Asmy Mohd Thas Thaker \\ Department of Economics, International Islamic University Malaysia, \\ Kuala Lumpur, Malaysia \\ Al Amin Mydin \\ School of Education, Universiti Sains Malaysia, Penang, Malaysia \\ Zubir Azhar \\ School of Management, Universiti Sains Malaysia, Penang, Malaysia, and \\ Abdul Rais Abdul Latiff \\ School of Social Sciences, Universiti Sains Malaysia, Penang, Malaysia
}

\begin{abstract}
Purpose - Waqf (Islamic endowment) in the form of cash is important to address the problem of developing idle waqf lands. Although there are various existing models of cash waqf, there is still a need for innovative cash waqf models. This paper aims to offer an alternative mode of financing for developing idle waqf lands using the concepts of cooperatives and waqf.

Design/methodology/approach - The present study first evaluates relevant literature on financing issues faced by waqf institutions in developing idle waqf lands as well as existing models of cash waqf. Based on the prevailing gap in cash waqf models, the study proposes a hybrid model of cooperative-waqf to finance idle waqf lands in Malaysia.

Findings - The proposed model is unique owing to the new dimension of membership being embedded into the waqf project. It considers donors as members of the waqf project, which is funded through the cash waqf collected, and thus, donors are given the privilege to receive benefits from the commercialised projects that are developed on the waqf lands. The existing models of cash waqf use traditional methods in which donors merely contribute cash waqf without any awareness of how the contributions are utilised. Usually, this problem occurs due to the lack of reciprocal communication between cash waqf donors and waqf institutions.

Research limitations/implications - The present study examines the case of waqf land development in the context of Malaysia only. Secondly, the paper does not contain any empirical analysis, and the development of the paper is based on existing literature that discusses various models of cash waqf practised
\end{abstract}

(c) Anwar Allah Pitchay, Mohamed Asmy Mohd Thas Thaker, Al Amin Mydin, Zubir Azhar and Abdul Rais Abdul Latiff. Published in ISRA International Journal of Islamic Finance. Published by Emerald Publishing Limited. This article is published under the Creative Commons Attribution (CC BY 4.0) licence. Anyone may reproduce, distribute, translate and create derivative works of this article (for both commercial and non-commercial purposes), subject to full attribution to the original publication and authors. The full terms of this licence may be seen at http://creativecommons.org/licences/by/4.0/legalcode

Funding: This research is funded by the Ministry of Higher Education (MOHE) under the grant of Fundamental Research Grant Scheme (203/ PMGT/6711551).

Cooperativewaqf model

Received 24 July 2017 Revised 18September 2017

24 January 2018

4 August 2018

15 August 2018

29 August 2018

Accepted 31 August 2018 
$\mathrm{IJIF}$

10,2 in Muslim-majority and -minority countries. Future research can conduct surveys of donors and other stakeholders on the practicality of the model.

Practical implications - It is expected that the proposed cooperative-waqf model will be able to create a synchronised relationship between cash waqf donors and waqf institutions and hence boost participation in developing waqf lands.

Originality/value - The present study adds to the existing literature in the area of waqf and cash waqf models, especially the application of this instrument in the context of Malaysia. It also offers a new hybrid model to the State Islamic Religious Councils (SIRCs) - Malaysia's sole trustee of waqf assets management such that the implementation of the proposed model could boost the collection of cash waqf in developing commercial projects on idle waqf lands.

Keywords Cash waqf, Cooperative-waqf

Paper type Conceptual paper

\section{Introduction}

Waqf is an Islamic voluntary contribution that was recommended by Prophet Muhammad (Peace Be Upon Him) during the early Islamic era. The word waqf literally means "restraining" and "stop" in Arabic. In Sharī'ah (Islamic law), waqf, as defined by the National Awqaf Foundation of South Africa, means a voluntary, permanent, irrevocable dedication of a portion of one's wealth, either in cash or in kind, to Allah. Waqf is recognized by the Shari' ah as one of the voluntary charitable acts that can be a source of funding for social and economic development. This voluntary instrument aims to establish a charitable scheme for improving the welfare of less-privileged segments such as the poor, insolvent, needy, orphans, widows and others (Cizakca, 2002). In addition, waqf has financed public services such as the building of mosques, religious educational institutions, libraries, hospitals, travellers' lodges and inns (McChesney, 1991). Notably, waqf played a key role in strengthening the spirit of brotherhood in Muslim societies, facilitating education and spreading the true spirit of Islam among Muslims (Siraj, 2012). The benefits of waqf assets are not restricted for the use of Muslim communities and religious activities but encompass broader scope of activities to improve and strengthen the development of social and economic conditions of a society (Cajee, 2007). However, waqf institutions and the contributions of waqf assets have not been sustainable, as indicated by Cizakca (2002). The evolution of waqf has gone through various developmental trends, including significant growth, stagnation and even periods of downturn. One of the main reasons for the latter phenomenon was Western colonisation (Aun, 1975).

Just as in most Muslim countries, the practice of waqf in Malaysia was negatively affected during the period of colonisation. The practice of waqf in Malaysia can be traced to the fourteenth century after the embracement of Islam by the Malacca Sultanate (Aun, 1975). During this period, some waqf properties were in the form of mosques and Islamic schools (Aun, 1975). The progressive development in waqf practice for a century after the Sultanate started it was truncated by the commencement of colonisation in Malaysia. The colonisation period began with the Portuguese from 1511 to 1641, was followed by the Dutch from 1641 to 1824 , and then by the British from 1826 to 1946. It had a devastating effect on the development of waqf in Malaysia. British occupation was interrupted from 1941 to 1945 due to the Second World War, during which the Japanese occupied Malaysia. The British regained the control of Malaysia from the Japanese in 1946. Malaysia became an independent country following the end of British colonisation in 1957. Abdullah (2009) observed that waqf practice went through tremendous changes during the post-colonial period in terms of the role of the trustee and the restructuring of waqf properties due to the 
loss of waqf deeds. Some waqf properties lost recognition of their waqf status due to the loss of supporting documents.

The Web portal i-Wakaf estimates the total size of waqf lands as recorded by the State Islamic Religious Councils (SIRCs), the sole trustee of waqf assets in Malaysia, to be around 8,861.13 ha. They are estimated to be worth about RM 63,729,855 (JAWHAR, Portal i-Wakaf, 2012). Although SIRCs have a huge number of potentially productive waqf lands, most of the lands remain idle. Jabatan Wakaf, Zakah dan Haji (JAWHAR) is a government institution that monitors the effectiveness and efficiency of waqf, zakāh and hajj

Cooperativewaqf model administration in every state in Malaysia. According to its former director Datuk Dr Sohaimi Mohd Salleh, 99.28 per cent of waqf lands remain undeveloped, mainly due to the shortage of financial resources (Mohammad, 2006). So far, the Malaysian Government has been funding the SIRCs for waqf projects and developments. In 2009, under the 9th Malaysian Plan (RMK-9), the Malaysian Government allocated RM 256.89m for this purpose. RM $244 \mathrm{~m}$ of it was for the development of 19 physical projects (including shop lots, mosques and others) and RM12.5m was for non-physical projects (including development of a database, websites and other online platforms). However, in 2010, under the 10th Malaysian Plan (RMK-10), the Government's allocation was reduced to RM 72.76m for economic reasons, and this could finance only ten selected projects (Berita Harian, 2012). Based on the total budget of RMK-9 and RMK-10, the SIRCs managed to develop only 0.16 per cent of the total waqf lands. The then Minister of Islamic Affairs suggested that the SIRCs require at least RM 80bn to develop all the waqf lands in Malaysia (Ngah, 2012).

The present challenges of waqf asset development in Malaysia have motivated the current research to formulate a sustainable model to generate cash waqf to assist waqf institutions in developing waqf lands in Malaysia. Besides government funding assistance, the SIRCs are using various models such as waqf shares, waqf takäful, direct waqf, mobile waqf and corporate cash waqf to boost the collection of cash waqf. According to the CEO of Perbadanan Wakaf Selangor (PWS), the collection of cash waqf is inconsistent. He attributes this to lack of waqf awareness and promotion and ineffective models of cash waqf for attracting more donors. These have failed to establish trust and a waqf culture among the Muslim community (Yang, 2014). Furthermore, he mentioned that participation from Islamic businesses and institutions (IBIs) is not at a satisfactory level even though the government offers a tax deduction of 10 per cent to organisations that contribute cash waqf. In addition, there are national cooperative institutions that focus on collecting cash waqf from their members for socio-economic enhancement. A leader in this area is the Malaysian National Co-operative Movement (ANGKASA) with its infāq lil-waqf program. This scheme has successfully attracted participation from many members and developed businesses, education, welfare, health and real estate projects, as well as rest and recreational areas. It is believed that SIRCs could adapt this cooperative-waqf model (CWM) as an alternative model to develop idle waqf lands facing funding constraints. The present study intends to propose and conceptualise a CWM that could help in boosting the collection of cash waqf and overcome the cash problem faced by SIRCs.

\section{Literature review}

Many past studies have attempted to solve the problem of idle waqf lands. Scholars have divided the mode of developing waqf lands into classical and modern methods. Among the earliest methods are $i b d \bar{a} l$ (exchange) and istibdāl (substitution) as the first two modes of developing idle waqf lands (Kahf, 1998; Mohammad, 2006). However, this mode faced an approval problem from jurists of different schools, generating divergent views among scholars on the issue. Furthermore, many cases of fraud occurred during the processes of 
ibdāl and istibdāl (Kahf, 1998; Mohammad, 2006). Other traditional modes are hikr (long-term lease with a large advance lump-sum payment) and ijärah (lease), which are used for the renovation of waqf properties (Mohammad, 2006). However, these two modes have shortcomings in that the lessee has a near perpetual right to utilize the waqf assets. Furthermore, they may be subject to fraud and corruption, particularly in terms of the use of profits generated from the sale of the long-term lease rights (Kahf, 1998).

Over time, waqf financing methods have evolved to also include cash waqf. The majority of researchers with management background have aggressively promoted various innovative models of cash waqf. For example, Sadeq (2002) proposed a model of financing based on issuance of waqf certificates. The mechanism of this model is as follows. The relevant waqf institution plans to build a project for the purpose of eradicating poverty and improving socioeconomic conditions. The project would be referred to a waqf administrative body (WAB) that would introduce it to the public and invite them to donate cash for financing the project. The cash waqf would be raised by issuing certificates in different denominations. The purpose of this model is to collect funds from the public and use them for a specific project.

Cizakca (2004), El-Gari (2004) and Abdel Mohsin (2008), on the other hand, proposed the establishment of an Islamic financial institution (IFI) based on waqf. The capital to set up the IFI would be generated from wealthy Muslims and cash waqf donors who would deposit cash waqf with the institution. The objective of this institution is basically to finance entrepreneurs through Islamic modes of financing such as qard hasan (interest-free loans).

Ahmed (2004) highlights the operational format of sukūk al intifā' (a time-sharing șukuk) using the example of King Abdul Aziz Waqf (KAAW) in Makkah. KAAW is a trustee that leased a piece of waqf land at the centre of Makkah for 28 years to the Bin Laden Group under the contract of Build-Operate-Transfer (BOT). In return, the group was to build the ZamZam Tower, consisting of a shopping complex, a tower and a hotel. The Bin Laden Group subcontracted the construction of the tower to Kuwait Real Estate Company (Manshaat), which undertook to finance the operation and operate it for 24 years. After 24 years, the whole project is expected to be transferred back to the Bin Laden Group after Manshaat benefits from an expected return of 26 per cent per annum, derived from the difference between the rental rates received from șukuk holders and the rate paid to the Bin Laden Group. The Manshaat Company issued US\$390 șukūk al intifă to raise funds from investors to finance construction of the project. The deal gave sukük holders the right to lease or utilize the specific units of the tower for the period of 24 years. The advantage of this model of financing is that after the concession period of 28 years both the waqf lands and projects that were developed on the waqf lands will be transferred to KAAW. Hence, KAAW will later fully manage the project, and the return generated from the project will be used to support social development. This type of financing is applicable for commercial development only because of the private participation required. The investors are seeking a return in addition to recovery of the construction cost.

Jalil (2008) proposed the use of cash waqf such as e-waqf, waqf shares and șukūk issuance to generate funding for waqf construction projects. Sukukk were also suggested by Mohammad (2006), who proposed the "in-house financing" method as well as securitization for the development of waqf properties. In-house financing constitutes obtaining advanced rentals under the concepts of hikr, ijärah, istibdāl and cash waqf. Securitization involves equity participation (including waqf-shares) and șukuk. Hassan and Shahid (2010) argue that there is a need to introduce stakeholders' șukūk in waqf institutions. An example of stakeholders is professionals. Professional business management techniques would undoubtedly create many opportunities to improve the quality of waqf institutions and delegate responsibility at the internal level of the institutions. 
Tohirin (2010) discussed cash waqf in relation to the empowerment of small businesses. He proposed the establishment of a waqf institution under the Islamic public finance sector that would be responsible for generating cash waqf from the society and providing financing for small and medium enterprises (SMEs). Affandi and Nufus (2010) proposed using cash waqf to overcome the government's inability to provide prosperity for the Indonesian people. The researchers suggested establishing an Indonesian waqf deposit (IWD) as a representative of cash waqf in Indonesia that would focus on methods of channelling cash waqf funds towards productive sectors. This study found the collection of cash waqf in Indonesia to still be far beneath expectation, with the most alarming shortfall occurring in the sector for rehabilitation of poor families.

Hasan (2011) proposed two waqf-based models for Muslim SMEs in Singapore, known as Amanah Saham Mendaki (Mendaki Growth Fund). This model is operated by Muslim cooperatives that promote waqf-based projects for the Muslim community. However, these models failed due to several factors such as lack of transparency, accountability, credibility, productivity and other reasons.

Alias (2012), in her conceptual paper discussed the application of certain venture capital (VC) strategies in both the investment and spending decisions of cash waqf. In its investment decisions, the cash waqf institution might utilise some of the tools employed by VC firms for choosing investments and mitigating risk. She also mentioned the possibility of a cash waqf institution considering certain VC opportunities as an alternative asset class in which to invest a portion of its corpus. In its spending decisions, the cash waqf institution may choose its beneficiaries in much the same way as VC firms would choose their investees; that is, by putting together a portfolio of non-profit organizations (NPOs) with proven track records for delivering social results and which seek to grow their organizations to achieve financial sustainability. Therefore, she proposes an Enterprise Waqf Fund model that combines the cash waqf model with relevant VC concepts to enhance the dynamics of cash waqf.

Hashim (2012) reviewed a case of waqf land development by the Penang State Islamic Religious Council (MAINPP). The land, located at Seberang Jaya Pulau Pinang, had been idle for many years due to MAINPP's lack of financial capital to carry out the development of the waqf property. The study found that a joint venture model, in which MAINPP collaborated with a housing developer (UDA Holdings Berhad), successfully developed the land into a housing project. The joint venture model implemented by MAINPP can be used as an example for other states in Malaysia to construct waqf property more productively.

Pitchay et al. (2015) examined the factors that influence the behavioural intention of Muslim employees in Klang Valley, Malaysia, to contribute cash waqf through salary deduction. The researchers employed the theory of reasoned action (TRA) to measure whether the attitude of the Muslim employees and subjective norms surrounding them have significant influence on their behavioural intention to contribute cash waqf through salary deduction. In total, 380 Muslim employees participated in this study, and the findings show that the attitude of the Muslim employees and the subjective norms surrounding them have significant influence on the behavioural intention of the employees to eventually contribute cash waqf.

Mohamad (2016) evaluated the cooperative-based institution known as ANGKASA, which offers a special co-operative social philanthropic scheme called infaq lit-waqf. This scheme provides opportunities for members to contribute cash, which is then transformed into the concept of waqf. This scheme is found to be significant in implementing important socio-economic projects in the areas of business, education, welfare, health, real estate and rest and recreation.

Pitchay et al. (2018) proposed a new cash waqf model which is integrated with mobile application platforms. The application is called the Awqaf Alternative Plan (AAP) model and specifically aims to generate cash waqf from staff, students and alumni of a tertiary 
education institution. Besides, the AAP model also addresses the problem of management at the level of universities, for instance, in estimating costs for organising a university event. This model is unique and its application can be extended to other institutions which have a large number of staff, students and other categories of individuals.

Based on the findings of past studies, the current study aims to adopt similar sentiments towards identifying an ideal and effective solution to boost the collection of cash waqf and mitigate the funding shortage faced by SIRCs. It proposes a new and innovative mechanism of collecting cash waqf through the cooperative model.

\section{Existing models of cash waqf}

There are various types of cash waqf models that are currently being practised in most Muslim-majority and Muslim-minority countries. Each of the models has its unique strength and contribution. The following delineates the modus operandi of some of the models.

\section{Waqf share scheme}

Waqf share scheme (WSS) is a public waqf practised in countries such as Malaysia, Indonesia, Kuwait and the UK (Abdel Mohsin, 2013). The objective of the scheme is to collect money from the public and to channel the funds for improving societal welfare. In general, the modus operandi of the WSS is as follows:

- Any specified institutions appointed by the government may establish this scheme and become the mutawallī (trustee).

- The appointed trustee will issue waqf shares in different values and sell the shares to donors for a specific project.

- The donors can buy the shares according to their affordability.

- The donors will receive cash waqf certificates as evidence of purchasing the waqf shares of the specified amount for the specified project.

- The amount collected from the sale of waqf shares will be managed by the trustee in terms of investment of the funds.

- The revenue generated from the investment will be used for financing the specified projects.

Abdel Mohsin (2013) averred that although there is no specific information on how the accumulated cash waqf was invested in these countries, these schemes have successfully provided goods and services to beneficiaries. Gadot (2006, cited in Abdel Mohsin, 2013) claimed that WSS gained popularity in the 1990s and was widely accepted as a scheme to raise funds that would later be invested. The revenue generated from the investment is reported to have financed many different types of projects. These include:

- developing existing waqf lands;

- constructing mosques and religious schools;

- financing medical facilities;

- providing physical amenities for Muslim communities;

- maintaining religious infrastructure;

- purchasing vehicles used in organising Islamic activities and events (e.g. for $d a^{\prime} w a h$ purposes); and

- building religious centres (SIRC Annual Report, 2009). 
Deposit cash waqf scheme

Under this scheme, the:

- donors contribute directly to the waqf institution by depositing money as cash waqf to a specific bank account;

- bank is responsible to invest the cash waqf according to the agreement with the waqf institution; and

- waqf institution will receive the revenue generated from the investment and will channel it to charities.

Abdel Mohsin (2013) informed that this scheme succeeded in providing different goods and services needed by the society. For example, in the case of Singapore, the deposit cash waqf scheme (DCWS) was established at the beginning of the twentieth century when the Muslimin Trust Fund Association was founded on 31 August 1904, following the contribution of cash waqf by Alsagoff and Co. and other Muslim businesses and individuals for investment purposes. Cizakca (2000) states that the key purposes of this investment were to finance the burial of poor Muslims, give aid to Muslim orphans, provide grants to the Alsagoff School and finance other charity projects.

Compulsory cash waqf scheme

Compulsory cash waqf scheme (CCWS) is a public waqf which has been practised only in Singapore. Abdel Mohsin (2013) demonstrates the modus operandi of CCWS as follows:

- Muslim employees' salaries are deducted through the Central Provident Fund (CPF) Board, i.e. Singapore's national social security organisation.

- Monthly contributions of between US\$1 and US\$7 are made by Muslim employees. The amount of deduction depends on the Muslim employee's monthly gross salary.

- The salaries of the Muslim employees are automatically deducted through an automatic check-off system whereby the salary is deducted by their employer and channelled through the CPF with Majlis Ugama Islam Singapore (MUIS) as the collecting agent.

The collected amount is to finance charitable purposes such as building and maintaining mosques, funding educational programmes and building $d a^{\prime}$ wah centres.

\section{Corporate waqf scheme}

Corporate waqf scheme (CWS) is a public waqf practised in Malaysia, Turkey, India, Pakistan and Bangladesh (Abdel Mohsin, 2013). The initiator of the scheme could be an individual or even private and public corporations. For example, in Malaysia, Wakaf An-Nur Corporation Berhad (WANCorp) is the first corporate waqf established under the Johor Corporation (JCorp) through the corporate waqf scheme (CWS). JCorp established WANCorp and declared RM 200m of JCorp net assets as waqf to WANCorp. This corporation was established to manage waqf organisations such as TPM Management Sdn Bhd and Larkin Sentral, which had been declared as waqf by JCorp. A periodical article by Bank Muamalat (2012) reported the accumulated total assets of WANCorp to be RM 538m. Hashim (2012) informed that altogether WANCorp operated 17 clinics in Malaysia, which have served more than 800,000 patients with a small charge of RM 5 per patient that covers the doctor's fee and medicines. The following provides the details of this model. 
$\mathrm{IJIF}$

10,2

\section{Deposit waqf product scheme}

This waqf scheme (deposit waqf product scheme) is similar to DCWS, but in this scheme, the bank acts as the trustee. Abdel Mohsin (2013) noted that this scheme has been practised by two banks in Bangladesh, the Social Investment Bank Limited (SIBL) and the Islami Bank Bangladesh Limited (IBBL). The modus operandi for this scheme is as follows:

- The founder deposits the cash waqf into the cash waqf-based account in SIBL or IBBL.

- Before depositing the money, the contributors are provided with a list of beneficiaries from which they can select, or the donor can specify its own beneficiaries.

- The bank acts as a trustee to collect and invest the cash waqf (capital) based on the mudāarabah contract.

- The revenue generated from the investment is then channelled to the said beneficiaries.

Currently, DWPS is practised in Malaysia where Bank Muamalat Malaysia Berhad (BMMB) acts as the special trustee appointed by the Selangor State Waqf Institution. The donors can deposit the cash waqf directly to BMMB account. BMMB is the institution responsible for investing the pooled deposit money. The return on investment (ROI) will then be channelled for education and health activities.

\section{The proposed cooperative-waqf model}

The proposed CWM in this study aims to address two issues, namely, to promote consistency among cash waqf donors and to solve the liquidity problem faced by waqf institutions. Figure 1 demonstrates the modus operandi of the CWM.

The following provides a detailed explanation of the workings of the CWM:

- Stage 1: Donors will contribute cash waqf to the waqf institution via various available methods of payment such as salary deduction (auto deduction according to a pre-agreed amount) or over-the-counter payment at the waqf institution (based on individual financial capacity). The waqf institution issues cash waqf certificates to the donors specifying the specific development projects that the cash waqf funds will be directed to, such as financing of mosques, schools or others. In the current practice of cash waqf, the role of donors stops at Stage 1. The donors do not have any idea how their cash is being utilised and they do not receive any incentive for 


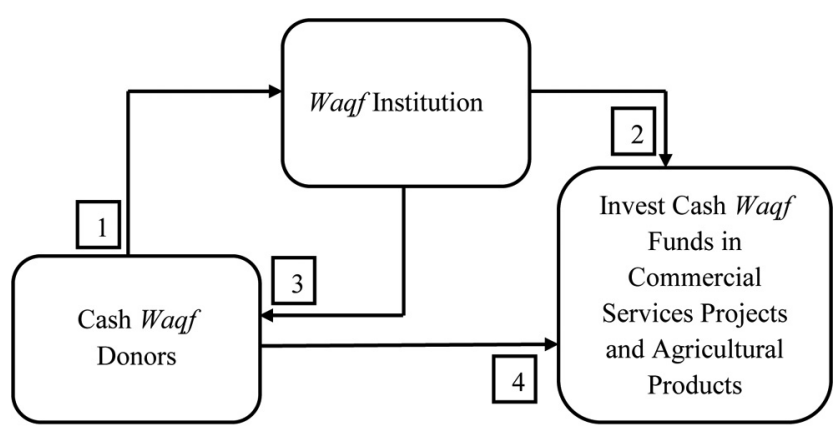

Cooperativewaqf model

Source: Authors

giving cash waqf, besides expecting rewards from Allah (SWT) and benefitting from an aggregate tax deduction from their income tax.

- Stage 2: The waqf institution will proceed to developing the projects.

- Stage 3: The waqf institution will issue membership cards called Sahabat Waqf to the donors who have contributed more than RM500 per annum. (The amount proposed in the study is unsupported and is subject to change by the waqf institution, which can set its own minimum amount to qualify as a member for a project). The membership element between the donors and the waqf institution is based on the cooperative concept.

- Stage 4: The function of this membership is to provide a privileged or a discounted rate to the donors when, for instance, they stay at any waqf-based commercial services project or purchase any agricultural products.

\section{Significance of the cooperative-waqf model}

There is currently no evidence in practice or in past literature that integrate the concept of waqf and cooperative in developing waqf assets. Therefore, the proposed model in this study is considered an innovative and integrated model that could be introduced by waqf institutions to the public.

This model has a high potential to enhance communication and interaction between donors and waqf institutions. Shortcomings in these areas are currently among the main constraints that impede the development of waqf assets by decreasing the level of trust among donors. The proposed model enhances the satisfaction of both parties. Membership privileges will enhance the level of donor trust. Moreover, consistent collection of cash waqf and development of waqf assets will improve the reputation of waqf institutions.

Besides the positive implication on the donors and waqf institutions, the CWM is expected to reduce the dependency of waqf institutions on government funding and will enable governments to divert their funding to meeting the essential needs of society at a comparatively lower price.

The CWM is also expected to contribute significantly to society as it encourages the circulation of money amongst the population in general instead of benefiting only the affluent. Increased public wealth circulation can overcome the problems created by capitalists in the society. 
At the level of the economy, the participation of Muslims in funding waqf projects will promote sustainable development and growth. This model will reduce dependency on interest-based loans and external borrowings for funding development projects.

\section{Conclusion}

The present study highlighted that a large number of waqf lands in Malaysia are still underdeveloped due to financial and management constraints faced by waqf institutions. The current method of cash waqf collection seems to be ineffective in generating sufficient funds for developing waqf lands. This study proposes the CWM, based on the concepts of cooperative and cash waqf, to develop potential waqf assets in Malaysia. The model can be further strengthened to increase cash waqf contributions and motivate more donors to participate in waqf-based development in Malaysia.

\section{References}

Abdel Mohsin, M.I. (2008), "Cash waqf a new financial product model aspects of Shariah principles on its commercialization", paper presented at the Islamic Banking, Accounting and Finance Conference (iBAF 2008), Kuala Lumpur, 28-29 July.

Abdel Mohsin, M.I. (2013), "Financing through cash-waqf: a revitalization to finance different needs", International Journal of Islamic and Middle Eastern Finance and Management, Vol. 6 No. 4, pp. 304-321.

Abdullah, M.S. (2009), "Malaysia perlu transformasi pengurusan wakaf", Utusan Malaysia, 25 December.

Affandi, A. and Nufus, D.N. (2010), "Analysis of cash waqf return fund allocation in Indonesia: a case study in Indonesian waqf deposit", The Tawhidi Epistemology: Zakat and Waqf Economy Proceedings of Seventh International Conference, Institut Islam Hadhari, UKM, Bangi, pp. 119-136, available at: www.ukm.my/hadhari/wp-content/uploads/2014/09/proceedingsseminar-waqf-tawhidi.pdf (accessed 3 March 2016).

Ahmed, H. (2004), Role of Zakah and Awqaf in Poverty Alleviation: Occasional Paper No. 8, Islamic Development Bank (IDB), Islamic Research and Training Institute (IRTI), Jeddah.

Alias, T.A. (2012), "Venture Capital strategies in waqf fund investment and spending", ISRA International Journal of Islamic Finance, Vol. 4 No. 1, pp. 1-54.

Aun, W.M. (1975), An Introduction to the Malaysian Legal System, Heinemann Educational Books (ASIA), Kuala Lumpur.

Bank Muamalat (2012), "Tokoh Ekonomi Islam: Tan Sri Muhammad Ali Hashim”, Al-Muamalat, p. 8 October.

Berita Harian (2012), "RM256.4 juta bangunkan 17 projek wakaf di Malaysia: Jamil Khir", 5 March, available at: www.bharian.com.my/articles/RM256_4jutabangunkan17projekwakafdiMalaysia_ JamilKhir/Article/index_html (accessed 5 April 2013).

Cajee, Z.A. (2007), "Revitalising the institution of awqaf in developing community", paper presented at the Singapore International Waqf Conference, Singapore, 6-7 March.

Cizakca, M. (2000), A History of Philanthropic Foundation: The Islamic World from the Seventh Century to the Present, Boğaziçi University Press, Ankara.

Cizakca, M. (2002), "Latest developments in the Western non-profit sector and the implications for Islamic awqaf', in Iqbal, M. (Ed.), Islamic Economic Institutions and the Elimination of Poverty, The Islamic Foundation, Leicester, pp. 263-287. 
Cizakca, M. (2004), “Cash waqf as alternative to NBFIs bank", paper presented at the International Seminar on Non-bank Financial Institutions: Islamic Alternatives, Kuala Lumpur, 1-3 March.

Cooperativewaqf model

El-Gari, M.A. (2004), “The Qard Hassan Bank”, paper presented at the International Seminar on Nonbank Financial Institutions: Islamic Alternatives, Kuala Lumpur, 1-3 March.

Gadot, N. (2006), "Amalan saham wakaf Johor", paper presented at the Konvensyen Wakaf, Kuala Lumpur, 12-14 September.

Hasan, S. (2011), "Role of waqf in enhancing Muslim small and medium enterprises (SMEs) in Singapore", paper presented at the 8th International Conference on Islamic Economics and Finance Sustainable Growth and Inclusive Economic Development from an Islamic Perspective, Doha-Qatar, 19-21 December.

Hashim, M.A. (2012), “Oxford sokong wakaf korporat”, Utusan Malaysia, 18 June, pp. 20-21.

Hassan, A. and Shahid, A. (2010), "Management and development of the awqaf assets", The Tawhidi Epistemology: Zakat and Waqf Economy Proceedings of Seventh International Conference, Institut Islam Hadhari, UKM, Bangi, pp. 309-328, available at: www.ukm.my/ hadhari/wp-content/uploads/2014/09/proceedings-seminar-waqf-tawhidi.pdf (accessed 3 March 2016).

Jalil, A. (2008), "Waqf instruments for construction contract: an analysis of structure", The Journal of Muamalat and Islamic Finance Research (JMIFR), Vol. 5 No. 1, p. 14.

JAWHAR, Portal i-Wakaf (2012), Portal i-Wakaf, available at: www.jawhar.gov.my/iwakaf/ (accessed 13 June 2012).

Kahf, M. (1998), Financing the Development of Awqaf Property, Seminar on Development of Awqaf by Islamic Research and Training Institute (IRTI), Kuala Lumpur.

McChesney, R.D. (1991), Waqf in Central Asia: Four Hundred Years in the History of a Muslim Shrine, 1480-1889, Princeton University Press, Princeton, NJ.

Mohamad, N.A. (2016), "Promoting community based waqf: a case study of co-operative society waqf in Malaysia", paper presented at the International Conference on Waqf and Economics Growth (ICWEG 2016), Jakarta, 9-10 November.

Mohammad, M.T.S. (2006), An Ideal Financial Mechanism for the Development of Waqf Properties in Malaysia, 2nd Edition, Universiti Teknologi Malaysia Press, Johor.

Ngah, N. (2012), available at: www.jawhar.gov.my/index.php/ms/akhbar/123-artikel-bh25102012 (accessed 5 April 2013).

Pitchay, A.A., Mydin Meera, A.K. and Saleem, M.Y. (2015), "Factors influencing the behavioral intentions of Muslim employees to contribute to cash-waqf through salary deductions", Journal of King Abdulaziz University: Islamic Economics, Vol. 28 No. 1, pp. 57-90.

Pitchay, A.A., Abdul Rahman, M.N.Y., Mohd Thas Thaker, M.A., Azhar, Z., Mydin, A.A. and Abd Jalil, M.I. (2018), "Proposing awqaf alternative plan (AAP): the way forward and sustainable higher education financial system", International Journal of Islamic Economics and Finance, Vol. 1 No. 1, pp. 39-57.

Sadeq, A. (2002), "Waqf, perpetual charity and poverty alleviation”, International Journal of Social Economics, Vol. 29 Nos 1/2, pp. 135-151.

Siraj, S.A. (2012), "An empirical investigation into the accounting, accountability and effectiveness of waqf management in the State Islamic Religious Councils (SIRCs) in Malaysia”, Doctoral thesis, Cardiff University, Cardiff.

Tohirin, A. (2010), "The cash waqf for empowering the small businesses", The Tawhidi Epistemology: Zakat and Waqf Economy Proceedings of Seventh International Conference, Institut Islam Hadhari, UKM, Bangi, pp. 485-500, available at: www.ukm.my/hadhari/wp-content/uploads/ 2014/09/proceedings-seminar-waqf-tawhidi.pdf (accessed 3 March 2016).

Yang, A.B (2014), The Challenges of Waqf Development in Malaysia, (Pitchay, A.A., Interviewer). 


\section{Further reading}

National Awqaf Foundation of South Africa (2018), "What is waqf", available at: www.awqafsa.org.za/ what-is-waqf/ (accessed 12 August 2018).

\section{About the authors}

Anwar Allah Pitchay, $\mathrm{PhD}$, is a Senior Lecturer at the School of Management, Universiti Sains Malaysia. He joined the university upon completing his $\mathrm{PhD}$ in 2015 from the International Islamic University Malaysia (IIUM). His research interests are in the areas of Islamic banking and finance and non-banking Islamic finance institutions (NBFI). He has achieved numerous recognitions of his achievements such as best paper award and postgraduate scholarships. Anwar Allah Pitchay is the corresponding author and can be contacted at: anwarap@usm.my

Mohamed Asmy Mohd Thas Thaker, PhD, obtained his Bachelor in Economics (Hons), Master of Economics and $\mathrm{PhD}$ in Economics from IIUM. Upon completion of his $\mathrm{PhD}$, he joined IIUM in October 2014 as Assistant Professor at the Department of Economics. Currently, he is Member and Research Fellow of the Centre of Islamic Economics, IIUM and Malaysian Economic Association.

$\mathrm{Al}$ Amin Mydin, $\mathrm{PhD}$, is a Senior Lecturer at the School of Educational Studies, Universiti Sains Malaysia. He completed his $\mathrm{PhD}$ in 2012 in the area of Leadership and Educational Management. He was a school administrator for more than six years before joining as an academic at Universiti Sains Malaysia.

Zubir Azhar, PhD, is a Senior Lecturer at the School of Management of Universiti Sains Malaysia. He is a Member of CPA (Australia) and a Chartered Accountant (CA) of the Malaysian Institute of Accountants (MIA). He obtained his PhD from the University of Manchester (UK) in 2015. Prior to joining USM in January 2016, he was a Senior Lecturer at the Faculty of Accountancy at the Universiti Teknologi MARA (UiTM).

Abdul Rais Abdul Latiff is trained in Energy and Climate Change Economics from Universiti Kebangsaan Malaysia (UKM), Malaysia. Prior to joining Universiti Sains Malaysia, he was a Junior Researcher at the Institute for Environment and Development (LESTARI, UKM). He is a member of the Malaysian Environmental Economics Association (MEEA).

For instructions on how to order reprints of this article, please visit our website: 